\title{
Red cell volume and cardiac output in anaemic preterm infants
}

\author{
I Hudson, A Cooke, B Holland, A Houston, J G Jones, T Turner, C A J Wardrop
}

\begin{abstract}
To test the hypothesis that haemoglobin concentration is a poor predictor of benefit from transfusion in preterm infants, and that red cell volume is the most important indicator of anaemia, 24 preterm infants receiving red cell transfusions had red cell volume, haemoglobin concentration, and cardiac output measured before and after transfusion. Red cell volume was measured either using dilution of autologous fetal haemoglobin with donor adult haemoglobin, or with a new technique using biotin as a red cell label. The two techniques give similar results. Mean (SD) values before transfusion were 27.4 (13.3), and after transfusion $45 \cdot 0(13.7) \mathrm{ml} / \mathrm{kg}$. Cardiac output was measured using imaging and Doppler ultrasonography, and fell with transfusion from mean 286 (121) to $251(95.6)$ $\mathrm{ml} / \mathrm{kg} / \mathrm{min}$. The red cell volume before transfusion correlated well with changes in cardiac output following transfusion, infants with a red cell volume before transfusion of less than $25 \mathrm{ml} / \mathrm{kg}$ showing a fall in cardiac output, and those with a red cell volume of greater than 25 $\mathrm{ml} / \mathrm{kg}$ not showing a significant fall. There was no correlation between haemoglobin concentration, packed cell volume, or change in packed cell volume with changes in cardiac output after transfusion.
\end{abstract}

A red cell volume of $25 \mathrm{ml} / \mathrm{kg}$ seems to be critical in preterm infants with anaemia, and infants with values below this are those most likely to benefit from transfusion.

Blood transfusions are commonly used in the management of preterm infants yet indications for transfusion and volumes of blood used vary widely. Haemoglobin concentration before transfusion is a poor predictor of benefit from red cell transfusion, ${ }^{12}$ and it has been suggested tht the red cell volume (synonymous with red cell mass) is theoretically a better guide to transfusion needs. ${ }^{3-5}$ The relationship between red cell volume and haemoglobin concentration varies $^{4-7}$; though some of this variation may be explained by differences in sampling sites for haemoglobin concentration, it may also be the result of differences in plasma volume among infants. Some infants have low red cell volumes, yet maintain a relatively normal haemoglobin concentration. ${ }^{4-6}$ The association of decreasing blood volume and a decreasing red cell volume may partly explain this phenomenon. ${ }^{36}$

In anaemic infants the packed cell volume is low. This reduces the oxygen carrying capacity of the blood but is partly compensated for by reduced viscosity of the blood and consequent reduced resistance to blood flow; flow increases thus partly restoring oxygen delivery. It has been calculated that the optimal packed cell volume for oxygen transport is about $40 \%{ }^{8}$ The effective reduction in peripheral vascular resistance should result in an increase in venous return and so in cardiac output.

An increased cardiac output has been found in anaemic adults ${ }^{9}$ as well as in newborn infants, ${ }^{10}$ and theoretically should also occur in anaemic infants. ${ }^{3}$

The purpose of this study was to investigate the value of measurements of red cell volume in predicting the need for, and benefit from, red cell transfusion defined by a fall in cardiac output.

Patients and methods

Cardiac output, red cell volume, haemoglobin concentration and packed cell volume were measured before and after red cell transfusions in 24 preterm infants without clinical evidence of patent ductus arteriosus. The decision to transfuse was made on clinical grounds independently of this study. Details of the infants are given in table 1 .

Ten infants were ventilated, four were being given supplementary oxygen, and 10 were breathing air at the time of study. Measurements were made while the infants were either asleep or in a quiet but alert state, and being nursed in an incubator or cot, as clinically indicated. As far as possible subsequent measurements were made with the infants in a similai state on each occasion.

\section{CALCULATION OF CARDIAC OUTPUT}

Cardiac output was calculated with a Vingmed CFM 700 Duplex ultrasound scanner with a 5 $\mathrm{MHz}$ probe. ${ }^{11}$ Spectral signals of aortic blood flow were recorded by continuous wave Doppler from the suprasternal site. Audio signals were later analysed on a Doptek spectrum analyser, which edits and calculates the mean blood flow

Table 1 Details of 24 infants (figures given are number of infants except where otherwise stated)

\begin{tabular}{ll}
\hline Gestation age (weeks): & \\
$24-26$ & 8 \\
$27-28$ & 4 \\
$29-30$ & 7 \\
$31-32$ & 3 \\
$33-34$ & 2 \\
Mean (range) age at transfusion (days) & $25(2-90)$ \\
Mean (SD) birth weight (g) & $1050(26)$ \\
Mean (SD) weight at time of study (g) & $1530(66)$ \\
\hline
\end{tabular}


velocity. Aortic diameter was measured from the $M$ mode echocardiogram through the aortic annulus using the trailing edge to leading edge method. The presence of a ductus arteriosus was defined using colour Doppler. If a ductus arteriosus was found the infants were excluded from later analysis because of uncertainties of the effect of transfusion on the size of the shunt.

The main limitation in the calculation of cardiac output is in the accurate measurement of aortic diameter. ${ }^{11}$ To overcome this the percentage change in cardiac output (expressed as $\mathrm{ml} / \mathrm{kg} / \mathrm{min}$ ) was calculated as follows:

$\frac{\text { Output before transfusion-output after transfusion }}{\text { Output after transfusion }} \times 100$

It was assumed that the aortic diameter measured at the annulus did not change appreciably in the 24 hours after transfusion, and this measurement was used on both occasions. The percentage change in cardiac output within an infant is therefore independent of the aortic diameter, thus enabling more accurate comparison among different infants.

Measurements were made before the blood transfusion and were repeated 12-24 hours afterwards.

MEASUREMENT OF RED CELL VOLUME

Red cell volume was measured by either diluting the fetal haemoglobin with donor adult haemoglobin ${ }^{4}$ or labelling the red cells with a biotin tracer. ${ }^{6}$ The former method could only be used if at least $20 \%$ fetal haemoglobin was present before the transfusion. This was possible in 20 infants. The concentration of fetal haemoglobin was accurately measured using an alkali denaturation technique. The biotin method for measuring red cell volume was used in four infants with low concentrations of fetal haemoglobin and also in six others at the same time as the dilution of fetal haemoglobin with donor adult haemoglobin as part of a previous study to confirm that the two methods gave similar results (table 2).

The technique for measuring red cell volume in preterm infants using biotin labelling of red cells has been described in detail previously. ${ }^{6}$ Autologous red cells were labelled with long chain water soluble biotin (NHS-LC-biotin sulfosuccinimidyl 6-(biotinamide))(Hexanoate, Pierce Chemical Company) and reinjected. Blood samples were then taken from the infant at 10 and 30 minutes and combined with fluorescein-streptavidin (Amersham International), which allowed the proportion of

Table 2 Simultaneous measurements of red cell volume $(\mathrm{ml} / \mathrm{kg})$ by biotin and dilution of fetal haemoglobin

\begin{tabular}{ll}
\hline Biotin & Dilution of fetal haemoglobin \\
\hline $28 \cdot 0$ & 30.5 \\
$26 \cdot 1$ & $27 \cdot 2$ \\
$20 \cdot 3$ & $20 \cdot 0$ \\
$13 \cdot 1$ & $16 \cdot 0$ \\
$19 \cdot 6$ & $19 \cdot 3$ \\
$16 \cdot 4$ & $15 \cdot 4$ \\
\hline Mean (SD) 20.6 (5.66) & $21 \cdot 4(6 \cdot 13)$ \\
\hline
\end{tabular}

positively labelled cells to be detected on a fluorescence activated cell sorter.

Haemoglobin concentration was measured in part of the blood sample taken for measurement of the red cell volume and was arterial if the infant had an indwelling arterial catheter, or venous if not.

\section{BLOOD TRANSFUSIONS}

Blood transfusions were given for clinical reasons such as blood loss caused by sampling or refractory anaemia of prematurity. About 30 $\mathrm{ml} / \mathrm{kg}$ of packed red cells $(20 \mathrm{ml} / \mathrm{kg}$ pure red cells) were given at each transfusion.

\section{Results}

The mean (SD) results of the simultaneous determination of red cell volume using biotin$20 \cdot 6(5 \cdot 7)$ - and dilution of fetal haemoglobin$21 \cdot 4(6 \cdot 1)$-were similar (table 2$)$. There was no significant difference between the results (paired $t$ test, $\mathrm{p}>0.05$ ).

The relationship between the red cell volume and haemoglobin concentration before transfusion is shown in fig $1(r=0.663)$.

Cardiac output, red cell volume and haemoglobin concentration are shown in tables 3 and 4. The overall difference in the cardiac output was significantly different after transfusion when compared with the values before trans-

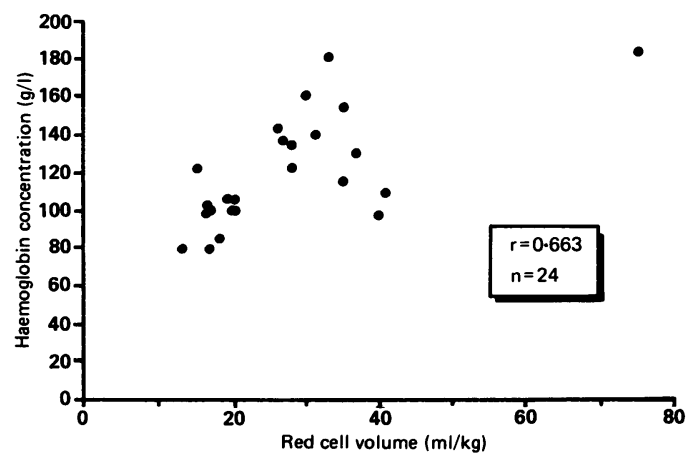

Figure 1 Association between red cell volume and haemoglobin concentration before transfusion.

Table 3 Mean (SD) values for cardiac output, red cell volume, and haemoglobin concentration in 24 infants

\begin{tabular}{lll}
\hline & $\begin{array}{l}\text { Before } \\
\text { transfusion }\end{array}$ & $\begin{array}{l}\text { After } \\
\text { transfusion }\end{array}$ \\
\hline $\begin{array}{l}\text { Red cell volume }(\mathrm{ml} / \mathrm{kg}) \\
\text { Haemoglobin concentration (g/l) }\end{array}$ & $\begin{array}{l}27 \cdot 4(13 \cdot 3) \\
120(29)\end{array}$ & $\begin{array}{l}45 \cdot 0(13 \cdot 7) \\
177(23)\end{array}$ \\
$\begin{array}{l}\text { Cardiac output (ml/kg/min): } \\
\quad \begin{array}{ll}\text { All infants } \\
\text { Infants without patent ductus } \\
\text { arteriosus (n=20) }\end{array}\end{array}$ & $286(121)$ & $251(95 \cdot 6)$ \\
\hline
\end{tabular}

Table 4 Mean (SEM) values for cardiac output, red cell volume, and haemoglobin concentration in 24 infants

\begin{tabular}{|c|c|c|}
\hline & $\begin{array}{l}\text { Before } \\
\text { transfusion }\end{array}$ & $\begin{array}{l}\text { After } \\
\text { transfusion }\end{array}$ \\
\hline $\begin{array}{l}\text { Red cell volume }(\mathrm{ml} / \mathrm{kg}) \\
\text { Haemoglobin concentration }(\mathrm{g} / \mathrm{l}) \\
\text { Cardiac output }(\mathrm{ml} / \mathrm{kg} / \mathrm{min}):\end{array}$ & $\begin{array}{l}27 \cdot 4(2 \cdot 6) \\
120(6)\end{array}$ & $\begin{array}{l}45 \cdot 0(2 \cdot 8) \\
177(5)\end{array}$ \\
\hline $\begin{array}{l}\text { All infants } \\
\text { Infants without patent ductus } \\
\text { arteriosus }(n=20)\end{array}$ & $\begin{array}{l}286(24 \cdot 7) \\
281(25 \cdot 9)\end{array}$ & $\begin{array}{l}251(19 \cdot 5) \\
240(19 \cdot 0)\end{array}$ \\
\hline
\end{tabular}




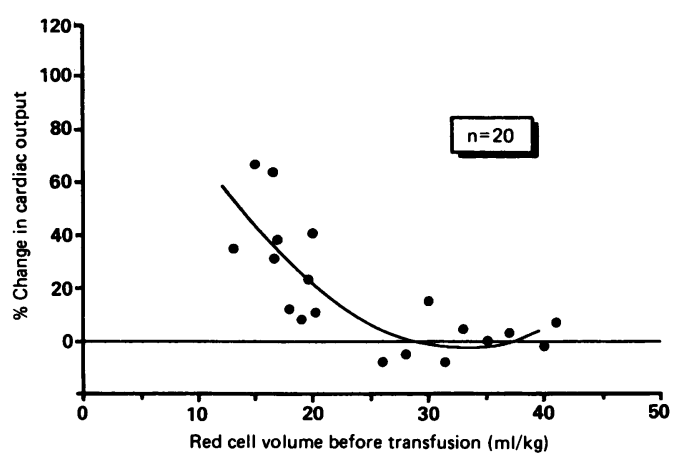

Figure 2 Association between red cell volume before transfusion and cardiac output before and after transfusion.

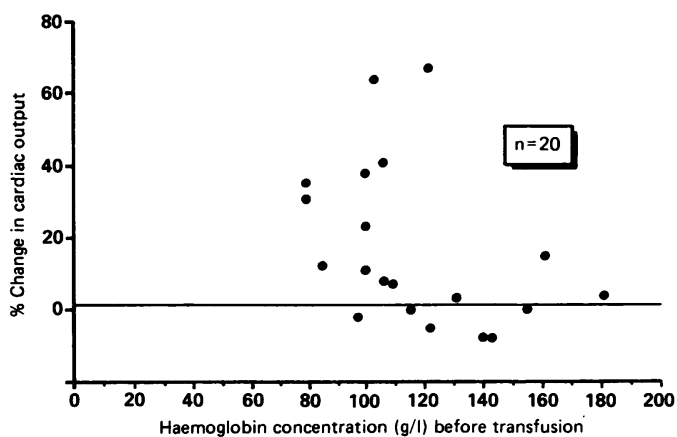

Figure 3 Association between haemoglobin concentration before transfusion and cardiac output before and after transfusion.

fusion (Student's $t$ test for paired samples, $\mathrm{p}<0.05)$.

Four of the 24 infants had patent ductus arteriosus shown on Doppler ultrasonography. Figure 2 shows the relationship between the percentage change in cardiac output and the red cell volume before transfusion for infants without patent ductus arteriosus. This relationship is expressed by the equation: percentage change in cardiac output $=153-9.44 \times$ red cell volume + $0 \cdot 143$ (red cell volume). ${ }^{2}$ The appropriate SE of the coefficients are $36,2 \cdot 9$, and 0.054 , and the $t$ ratios $4 \cdot 26,-3 \cdot 22$, and $2 \cdot 64$. $R-s q=65 \cdot 0 \%$. The estimated standard deviation of the percentage change is $14 \cdot 04$. Clearly all terms in the relationship are significantly different from zero. It shows that those infants with a red cell volume of more than $25 \mathrm{ml} / \mathrm{kg}$ before transfusion did not have a significant fall in cardiac output, whereas those infants who had a red cell volume of less than $25 \mathrm{ml} / \mathrm{kg}$ before transfusion did have a significant fall in cardiac output. There was no significant relationship between the percentage change in cardiac output and haemoglobin concentration before transfusion (fig 3), $(R-s q=15 \cdot 5 \%)$. Similarly there was no significant relationship between percentage change in cardiac output and packed cell volume before transfusion ( $R-s q \quad 15 \cdot 1 \%$ ), change in packed cell volume $(R-s q 6.6 \%)$, or change in haemoglobin concentration ( $r-s q$ $4 \cdot 1 \%)$.

\section{Discussion}

The ability to predict benefit from blood transfusion reliably would permit better prescribing of red cell transfusion, and would lead to a reduction in exposure to donors and hence the risks of transfusion transmitted infection. This study confirms the variable relationship between red cell volume and haemoglobin concentration, and this may partly explain why the haemoglobin concentration is a poor predictor of benefit from blood transfusion. Measurements of cardiac output and red cell volume were made before and after blood transfusion. In the analysis of the results, infants in whom patent ductus arteriosus was found either before, after, or both before and after $(n=4)$, were excluded. Alverson et al found that infants with patent ductus arteriosus had increased cardiac output, ${ }^{12}$ and it is not yet fully established what the effect of transfusion is on shunt size in these infants.

The mean cardiac output was significantly lowered after transfusion; others, however, have not found this change to be significant. ${ }^{1}$ In the present study larger volumes of red cells were used (about $20 \mathrm{ml} / \mathrm{kg}$ ) than in other studies, ${ }^{10}$ and continuous wave Doppler was used in preference to pulsed Doppler. We have previously found continuous wave Doppler to be more reproducible than pulsed Doppler in calculating of cardiac output in newborn infants. ${ }^{11}$

Jones et al predicted a biological response from theoretical considerations of perfusion and packed cell volume, which would occur when the red cell volume fell to between 15 and 25 $\mathrm{ml} / \mathrm{kg}^{3}$ This response could be an increase in cardiac output. In the 20 infants without evidence of patent ductus arteriosus the percentage change in cardiac output with transfusion was similar to the predicted biological response, and was significantly related to the red cell volume before transfusion. Those infants with a red cell volume of less than $25 \mathrm{ml} / \mathrm{kg}$ showed the greatest fall and those infants with red cell volume of greater than 25 showed no significant change. There was no significant association with haemoglobin concentration, packed cell volume, change in haemoglobin concentration, or change in packed cell volume.

It might have been expected that the change in cardiac output would have had a stronger association with the change in packed cell volume (fig 4) because of considerations of flow and blood viscosity. The lack of relationship

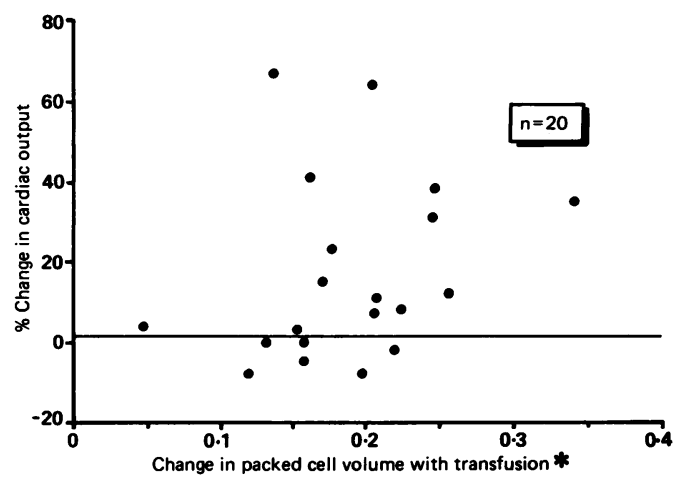

Figure 4 Association between change in packed cell volume with transfusion and cardiac output before and after transfusion. *Packed cell volume after transfusion-packed cell volume before transfusion. 
found in this study may be the result of several factors. Firstly, the sampled packed cell volume may bear only a limited association to total body packed cell volume (red cell volume/total blood volume). Correction factors have been derived to correct for total body to venous packed cell volume ratios, but these are mean values for a number of newborn infants and considerable individual variation might be expected. ${ }^{13} 14$ The relationship between total body and venous packed cell volume ratios have not been fully investigated in sick newborn infants, and the individual variation may be even greater. Secondly, total blood volume, which appears to be related to red cell volume, ${ }^{36}$ may play an important part. There seems to be no evidence that plasma volume expands in anaemic infants, ${ }^{3}$ and therefore in these infants with reduced red cell volume the effect of a reduction in blood volume and shunting to maintain flow to vital organs is superimposed on the effects of a reduced packed cell volume. Bifano et al found that albumin infusions given to anaemic infants relieved the apnoea that had been attributed to the anaemia, at least during the 24 hours after the infusion. ${ }^{15}$ It seems likely, therefore, that some of the symptoms attributed to the anaemia of prematurity are the result of the reductions in blood volume found in anaemic infants.

This study clearly shows that changes in cardiac output associated with transfusion were significantly related to red cell volume but not to haemoglobin concentration or packed cell volume. Red cell volume may therefore be a better guide for decisions on when to transfuse and a better predictor of benefit from tranfusion.
I H was supported by a grant from Scottish Hospitals Endowment Research Trust. We thank the staff of the medical illustration department, Royal Hospital for Sick Children, Glasgow, for their help with the illustrations and $\mathrm{Mr} \mathrm{T}$ Aitchison for advice and help with the statistical analysis.

1 Alverson DC, Isken VH, Cohen RS. Effect of booster blood transfusions on oxygen utilisation in infants with bronchopulmonary dysplasia. $\mathcal{f}$ Pediatr 1988;113:722-6.

2 Blank JP, Sheagren TG, Vajaria J, Mangurten HH, Benawra RS, Puppala BL. The role of RBC transfusion in the preterm infant. Am $\mathcal{F}$ Dis Child 1984;138:831-3.

3 Jones JG, Holland BM, Kinmond S, Phillips HM, Turner TL, Wardrop CAJ. Prediction and attainment of optimal TL, Wardrop CAJ. Prediction and attainment of optim
red cell mass in neonates. Pediatr Res 1989;25:374A.

red cell mass in neonates. Pediatr Res 1989;25:374A.
4 Phillips HM, Holland BW, Abdel-Moiz A, et al. Determination of red cell mass in the assessment and management of anaemia in babies needing blood transfusion. Lancet 1986;i:882-4.

5 Holland BM, Jones JG, Wardrop CAJ. Lessons from the anaemia of prematurity. Hematol Oncol Clin North Am 1987;1:355-66.

6 Hudson IRB, Cavill IAJ, Cooke A, Holland BM, Turner TL, Wardrop CAJ. Biotin labelling of red cells in the measurement of red cell mass in preterm infants. Pediatr Res 1990 (in press).

7 Blanchette VS, Zipursky A. Assessment of anemia in newborn infants. Clin Perinatol 1984;11:489-510.

8 Stone HA, Thomson HK, Jr, Schmidt-Nielsen K. Influence of erythrocytes on blood viscosity. Am $\mathcal{F}$ Physiol 1968;214:

9 Duke $M$, Abelman WH. The hemodynamic response to chronic anemia. Circulation 1969;39:503.

10 Bifano E, Smith F, Borer J, Goldwasser E. Oxygen supply and demand in infants with anemia of prematurity with and without apnea. Pediatr Res 1988;3:461A.

11 Hudson I, Houston A, Aitchison T, Holland B, Turner T. Reproducibility of measurements of cardiac output in newborn infants by Doppler ultrasound. Arch Dis Child 1990;65:15-9.

12 Alverson DC, Eldridge MW, Johnson JD, et al. Effect of patent ductus arteriosus on left ventricular output in premature infants. 7 Pediatr 1983;102:754

13 Mollison PL, Veall N, Cutbush M. Red cell and plasma volume in newborn infants. Arch Dis Child 1950;25: 242-53.

14 Bratteby LE. Studies on erythro-kinetics in infancy viii: mixing, disappearance rate and distribution volume of mixing, disappearance rate and distribution volume of Acta Soc Med Uppsal 1967;72:249.

15 Bifano E, Borer J, Smith F, Consenstein L, Goldwasser E. Effect of transfusion on apnea of prematurity: red cells or volume? Pediatr Res 1988;23:402A. 